Research article

\title{
Detection and identification of microbial contaminants from plant tissue culture
}

\author{
Mohit Dangariya ${ }^{1}$, Dharam Khandhar ${ }^{1}$, Jagdishchandra Monpara ${ }^{1,2}$, \\ Kiran Chudasama ${ }^{1} *$ and Vrinda Thaker ${ }^{1}$ \\ ${ }^{1}$ Plant Physiology and Molecular Biology Lab, UGC-CAS Department of Biosciences, \\ Saurashtra University, Gujarat, India \\ ${ }^{2}$ Vimal Research Society for Agro-Biotech and Cosmic Powers, Rajkot-360002, Gujarat, India \\ *Corresponding Author: kiranchudasama@gmail.com \\ [Accepted: 22 July 2020]
}

\begin{abstract}
Microbial contamination is a major problem, which affects the growth and development of the plant in micropropagation techniques. In the present study, the aim was to investigate the source of microbial contamination in the tissue culture laboratory. In the present work, microbes were isolated from the contaminated different plant tissue culture tubes. Isolated fungi were inoculating on Potato Dextrose Agar and incubated for 5 days at $37^{\circ} \mathrm{C}$ in case of fungi and bacteria on Nutrient Agar medium incubated for 2 days at $37^{\circ} \mathrm{C}$. Total of 28 isolates obtained which include nineteen fungi and nine bacteria. It was sub-cultured for isolation, identified by morphological and molecular techniques. For identification of the strain, genomic DNA was isolated and amplified by universal primer and amplified DNA fragments were separated by electrophoresis. Bacteria and fungi were identified by $16 \mathrm{~S} r D N A$ and $28 \mathrm{~S} r D N A$ gene sequencing, respectively. Purified PCR product was preceded for cycle sequencing and sequenced on 3130 Genetic analyzer (Applied Biosystem, USA). All the obtained sequences were submitted in NCBI database. These fungal and bacteria were found to cause the death of the culture material. Probable sources of contamination in plant tissue culture laboratory were discussed.
\end{abstract}

Keywords: Bacteria and fungi - Contamination - Plant tissue culture - Identification.

[Cite as: Dangariya M, Khandhar D, Monpara J, Chudasama K \& Thaker V (2020) Detection and identification of microbial contaminants from plant tissue culture. Tropical Plant Research 7(2): 388-395]

\section{INTRODUCTION}

Plant cell and tissue culture is an important tool for the aseptic production of cells, tissues and organs in both basic and applied research. It has been extensively used for mass production of elite plants as well as to study the basic aspects of primary and secondary metabolism, morphogenesis, biotransformation of pharmaceuticals, production of proteins including antibiotics and genetic engineering, manipulation and massive production of plants in the horticultural industry (Singh \& Shetty 2011, Hussain et al. 2012, Bhargava et al. 2018, Borpuzari $\&$ Bisht 2019). The nutrient media in which the plant tissue cultivated is contained the macro and micro nutrient, carbohydrate, organic acid, amino acid and vitamins. It is a good source for microbial growth. These microbes compete adversely with plant tissue culture for nutrients. Tissue culture contamination frequently originates during any stages it includes explants contaminated with bacteria and fungi may be endophytic or epiphytic, may be pathogenic or saprophytic and normal flora of environment (Debergh \& Maene 1984). The contamination of microorganism in plant tissue culture generally increased the rate of culture mortality, the presence of latent infections can also result in variable growth, tissue necrosis, reduced shoot proliferation and reduced rooting (McCown 1986, Kane 2003). The microbial contamination by yeasts, fungi, bacteria and viruses are the major problem that affects the establishment of aseptic plants and their successful micropropagation (Odutayo et al. 2007).

Nowadays micropropagation is used for the development of the plant with pest or stress resistance and pathogen-free plant production (Sharma \& Agrawal 2012, Kolomiets et al. 2014, Malyarovskaya \& Samarina 
2017). During the last few years, micropropagation techniques have been widely used for the propagation of several plant species of medicinal, fruit trees and floriculture (Rout \& Jain 2004, Hassan \& Zayed 2018). It is very important that in vitro cultures are free of biological contamination and are maintained as aseptic cultures during manipulation, growth and storage. Although, the plant materials used in tissue culture are disinfected using surfactants to remove microbes and all vessels and media were sterilized properly (George 1993), there are some reports in which microbial contamination in tissue culture is said to restrict the development of all in vitro techniques (Leifert \& Cassells 2001). Each step of the plant tissue culture process required to prevent contamination from the handling of mother plants and explants, media preparation, subculturing and incubation of plant cultures. Preventing microbial contamination of plant tissue cultures is critical to successful micropropagation. Therefore rapid production of contamination-free plants is a fundamental goal of the micro-propagation process, this study aimed to investigate and identify the microbial contamination of plant tissue cultures.

\section{MATERIALS AND METHODS}

The work was done in Tissue Culture Laboratory, Vimal Research Society for Agro-Biotech and Cosmic Powers, Rajkot, Gujarat (India) during the period from April 2018 to March 2019. The explants like the leaf, nodal meristem, embryo and callus were used for the culture and inoculated in Murashige and Skoog, (MS) medium (Murashige \& Skoog 1962). The medium was sterilized by autoclaving at $121^{\circ} \mathrm{C}$ for 15 min pressure. The explants were excised and surfaced sterilized with $0.1 \%$ mercury chloride $\left(\mathrm{HgCl}_{2}\right)$, washed thrice using distilled water. Further, it was dipped in $70 \%$ ethanol for 30 seconds and washed thrice with sterile distilled water. Then, it's dipped in antibiotic solution Bavistin for $10 \mathrm{~min}$, washed with sterile distilled water. Sterilized explants were aseptically inoculated in MS medium, labelled and incubated at $24 \pm 2^{\circ} \mathrm{C}$ for two weeks. Contaminated tissue culture tubes were removed from the Tissue Culture lab and visually examined.

\section{Isolation of microbial contaminants}

Form the contaminated plant tissue culture tubes fungi were isolated and grow on Potato Dextrose Agar and incubated for 5 days at $37^{\circ} \mathrm{C}$ and bacteria were culture on $\mathrm{N}$-agar medium for $48 \mathrm{~h}$ at $37^{\circ} \mathrm{C}$. Pure isolates obtained from repeated sub-culturing of culture.

\section{Maintenance of culture}

Isolated bacteria were sub-cultured on nutrient agar medium at regular intervals, incubated at $37^{\circ} \mathrm{C}$ for $24 \mathrm{~h}$ and preserved at $4^{\circ} \mathrm{C}$ for further study. Fungi were preserved in sterile distilled water. Bacterial morphological examination of the isolates was done by Gram's staining techniques. Fungal Morphological and microscopical identification was carried out by observing the growth pattern, and color of hyphae.

\section{Identification of bacteria and fungi}

Fungal DNA was isolated according to the Rabari et al. (2018) and bacterial DNA was isolated according to (Chudasama \& Thaker 2012). The purity and concentration of genomic DNA was measured at absorbance 260/280. For fungi identification $28 S$ rDNA gene was amplified using the MicroSeq ${ }^{\circledR}$ D2 LSU rDNA Fungal Identification Kit and $16 s$ rDNA gene was used for bacterial identification, amplified using the universal primer. The amplified DNA fragments were separated by electrophoresis through $1.5 \%$ agarose gel. The purified PCR products were sequenced using a Big Dye Terminator V 3.1 Cycle Sequencing Kit using ABI 3130 genetic analyzer.

\section{Nucleotide sequence accession numbers}

The nucleotide sequences determined in this study have been submitted to the NCBI GenBank database.

\section{RESULTS AND DISCUSSION}

The technique of in vitro cultivation of plant cell or organ mainly depends on two basic effects (i) to keep the plant cells and organs free from microbial contamination (ii) to develop in the cell and organs by providing suitable nutrient media and other environmental conditions. The presence of microbes in the form of contamination in plant cell culture results in increased the mortality of cell in the culture, and cause the tissue necrosis, reduced the shoot and root proliferation (Msogoyo et al. 2012). Tissue culture media contained a high concentration of carbohydrate source i.e. the sucrose, which supports the growth of many bacteria and fungi. In nutrient-rich medium these microbes generally grow very fast than the plant cell. These microbes secrete metabolic wastes that are toxic to plant tissues and finally kill the plant cells. Therefore it is essential to maintain a completely aseptic environment throughout plant tissue culture techniques. Bacteria and fungi which 
contaminate plant cultures originate from the laboratory environments, sterilization techniques, operators, mites and thrips (Singh 2018). Each step of plant tissue culture protocol should be performed carefully to prevent contamination. Therefore the first objective of this study was to proper sterilization of explants and prevention of contamination in tissue culture laboratory it is necessary to identify the organism.
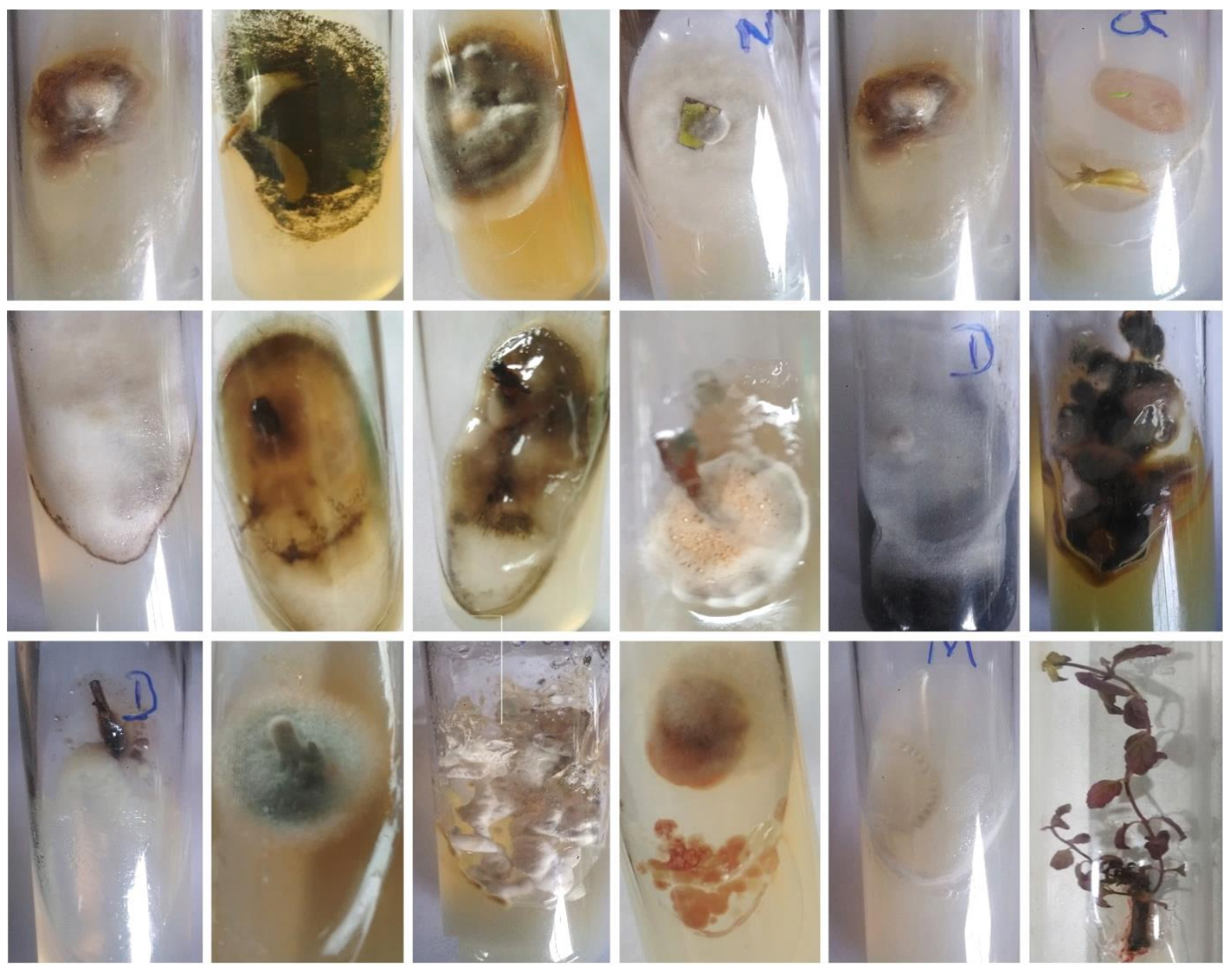

Figure 1. Contaminated plant tissue culture tubes.

Table 1. Morphological characteristics of fungi on PDA.

\begin{tabular}{llll}
\hline S.N. & Strain & Hyphal Morphology & Spore \\
\hline 1 & Fusicolla violacea (SUF69) & Black & Present \\
2 & Lasiodiplodia pseudotheobromae (SUF70) & Grey & Present \\
3 & Aspergillus niger (SUF71) & Green & Present \\
4 & Epicoccum nigrum (SUF72) & Green & Present \\
5 & Aspergillus parvulus (SUF73) & Orange & Present \\
6 & Talaromyces funiculosus (SUF74) & Green & Present \\
7 & Talaromyces funiculosus (SUF75) & Green & Present \\
8 & Aspergillus flavus (SUF76) & Green & Present \\
9 & Aspergillus parasiticus (SUF77) & Green & Present \\
10 & Fusarium solani (SUF78) & Pink & Present \\
11 & Rhizopus oryzae (SUF79) & Brown & Present \\
12 & Clitopilus giovanellae (SUF80) & White & Present \\
13 & Simplicillium obclavatum (SUF81) & Orange & Present \\
14 & Aspergillus leporis & Green & Present \\
15 & Fusicolla violacea (SUF83) & White & Present \\
16 & Aspergillus keveii (SUF84) & Green & Present \\
17 & Pseudocercospora hakeae (SUF85) & Brown & Present \\
18 & Rhizopus oryzae (SUF86) & Brown & Present \\
19 & Colletotrichum asianum (SUF87) & White & Present \\
\hline
\end{tabular}

Considering these, in the present study, a total of 28 organisms were isolated from different contaminated plant tissue culture tubes (Fig. 1). Out of the twenty-eight organisms, nineteen are fungi and nine bacterial strains obtained. Isolated fungi strains were initially designated as SUF69-SUF87, and examined for their 
structure, color and presence or absence of spore in the microscope (Table 1; Fig. 2). Further it was identified by $28 S$ rDNA sequencing. For their molecular identification DNA extraction of 19 isolates were carried out. In the present study, using the universal primer set, 325bp DNA fragment of the 28S rDNA gene was amplified by PCR (Fig. 3). These PCR products were cycle sequenced using Genetic Analyzer ABi 3130. NCBI BLAST tool was used to confirm the percentage identity with relative fungi available in database. It was found that the identity ranged from 89-100\% (Table 2). The strains SUF69-SUF87 showed similarity with Fusicolla violacea, Lasiodiplodia pseudotheobromae, Aspergillus. niger, Epicoccum nigrum, Aspergillus parvulus, Talaromyces funiculosus, Talaromyces funiculosus, Aspergillus flavus, Aspergillus parasiticus, Fusarium solani, Rhizopus oryzae, Clitopilus giovanellae, Simplicillium obclavatum, Aspergillus leporis, Fusicolla violacea, Aspergillus keveii, Pseudocercospora hakeae, Rhizopus oryzae and Colletotrichum asianum respectively. Earlier Odutayo et al. (2004) isolated the Alterneria tenius, A. niger, A. fumigatus and Fusarium culmorum and Rhizopus oryzae from plant tissue cultures in Nigeria. Miller et al. (1988) and Kane (2003) have observed the common indoor fungi Cladosporium, Penicillium, Aspergillus and Alternaria as contamination in plant tissue culture.

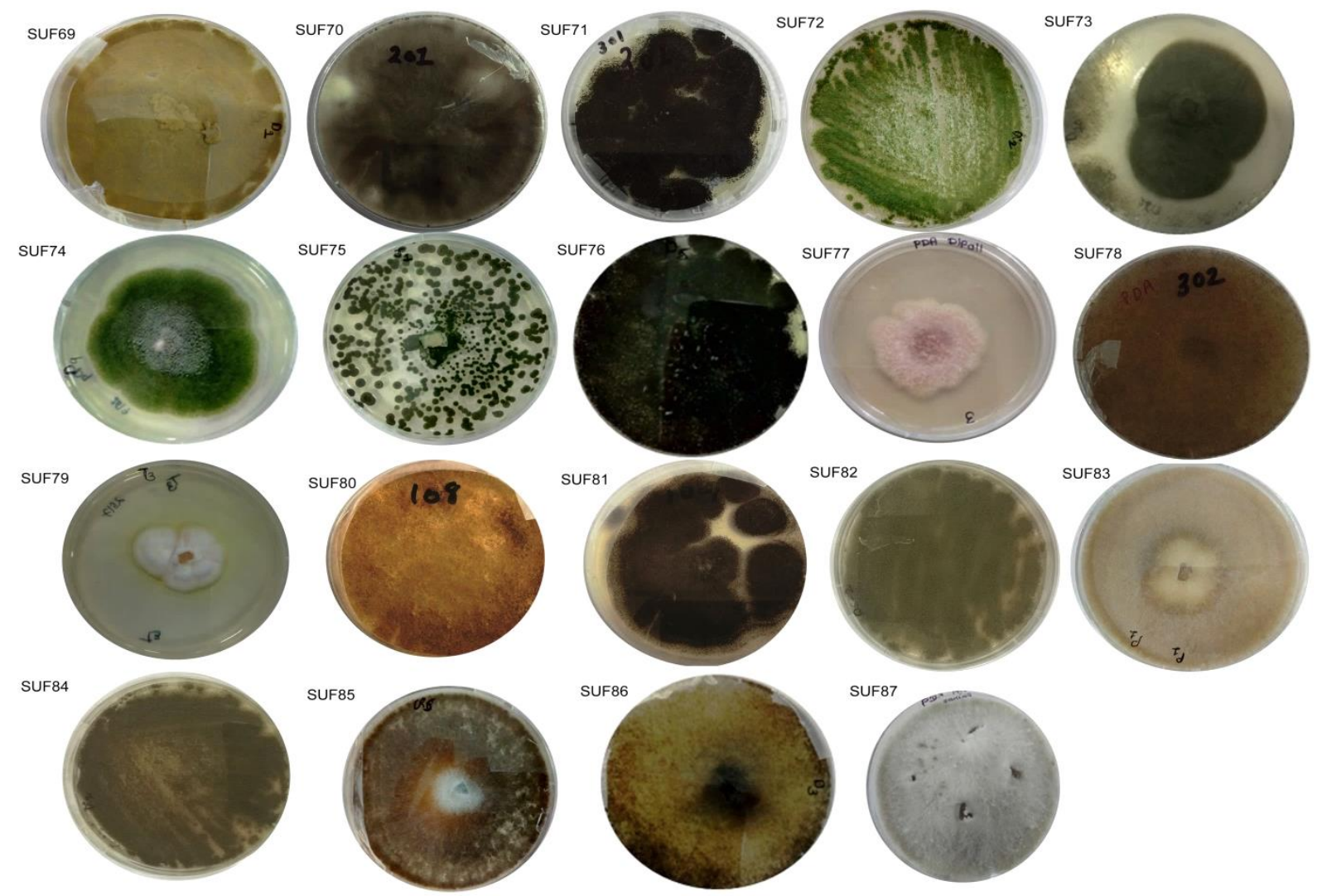

Figure 2. Morphology on PDA medium.
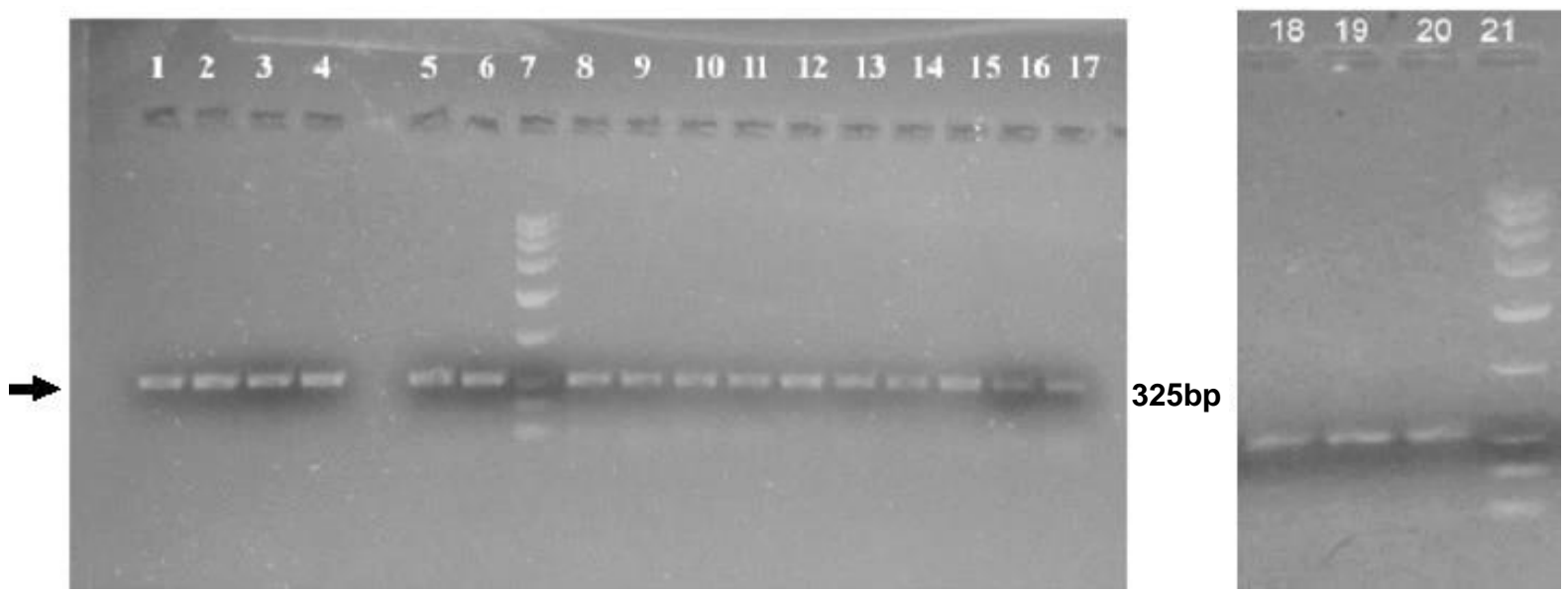

Figure 3. Agarose gel electrophoresis of amplified $28 s \mathrm{rDNA}$ gene, 325bp product using universal primer (lane : (1) SUF69 (2) SUF70 (3) SUF71 (4) SUF72 (5) SUF73 (6) SUF74 (7) Marker (8) SUB75 (9) SUF76 (10) SUF77 (11)SUF78 (12)SUF79 (13) SUF80 (14) SUF81 (15) SUF82 (16) SUF83 (17) SUF84 (18)SUF85 (19)SUF86 (20)SUF87 and (21) Marker respectively. 
Table 2. Fungi isolated from tissue culture materials and sequence accession number.

\begin{tabular}{lllll}
\hline S.N. & Name of fungi & Isolation source & Accession No. & Similarity (\%) \\
\hline 1 & Fusicolla violacea (SUF69) & Punica granatum & MK788155 & 92 \\
2 & Lasiodiplodia pseudotheobromae (SUF70) & Punica granatum & MK788156 & 97 \\
3 & Aspergillus niger (SUF71) & Punica granatum & MK788157 & 95 \\
4 & Epicoccum nigrum (SUF72) & Punica granatum & MK788165 & 98 \\
5 & Aspergillus parvulus (SUF73) & Punica granatum & MK788166 & 95 \\
6 & Talaromyces funiculosus (SUF74) & Gerbera jamesonii & MK788167 & 89 \\
7 & Talaromyces funiculosus (SUF75) & Punica granatum & MK788168 & 90 \\
8 & Aspergillus flavus (SUF76) & Punica granatum & MK788169 & 96 \\
9 & Aspergillus parasiticus (SUF77) & Punica granatum & MK788170 & 98 \\
10 & Fusarium solani (SUF78) & Punica granatum & MK788171 & 99 \\
11 & Rhizopus oryzae (SUF79) & Gerbera jamesonii & MK788172 & 98 \\
12 & Clitopilus giovanellae (SUF80) & Tinosporia cordifolia & MK788173 & 95 \\
13 & Simplicillium obclavatum (SUF81) & Rosa indica & MK788174 & 99 \\
14 & Aspergillus leporis & Gerbera jamesonii & MK788175 & 95 \\
15 & Fusicolla violacea (SUF83) & Carica papaya & MK788176 & 92 \\
16 & Aspergillus keveii (SUF84) & Piper betel & MK788177 & 98 \\
17 & Pseudocercospora hakeae (SUF85) & Ocimum tenuiflorum & MK788178 & 100 \\
18 & Rhizopus oryzae (SUF86) & Mentha piperita & MK788179 & 91 \\
19 & Colletotrichum asianum (SUF87) & Rosa indica & MK788180 & 95 \\
\hline
\end{tabular}

Aspergillus, Fusarium, Penicillium and Talaromyces are some of the genera of fungi which belong to the family of filamentous fungi (Chen et al. 2016, Egbuta et al. 2017). Filamentous fungi occur widely found in soil, air, food, plant surface and other substrates (Cassells 1991, More et al. 2010). Filamentous fungi are found commonly in the environment due to the ability of this group of fungi to grow on almost any substrate and under harsh conditions. The genera Aspergillus, Fusarium, Penicillum and Colletotrichum were the most reported as endophytic fungi in the plant from India and worldwide (You et al. 2012, Kannan et al. 2014, Masumi et al. 2015).

The establishment of a commercial protocol for in vitro propagation depends on control and prevention of environmental and endophytic contamination during all subsequent in vitro stages (Danby et al. 1994, Tolera et al. 2014). The micro-arthropods presence in a laboratory environment can actively enter the culture tube and introduce fungal spores and bacterial contaminants in tissue cultures (Leifert \& Cassells 2001, Cassells 2012).

Table 3. Morphology and colony characteristics of isolated strain.

\begin{tabular}{|c|c|c|}
\hline Bacterial strain & Colony Characteristic & Morphology \\
\hline Kocuria palustris (SUB61) & $\begin{array}{l}\text { Smooth, opaque, irregular, } \\
\text { yellow }\end{array}$ & Gram positive \\
\hline Enterobacter asburiae (SUB62) & $\begin{array}{l}\text { Round, raised, translucent, } \\
\text { smooth, yellow }\end{array}$ & Gram negative \\
\hline Aeromonas caviae (SUB63) & $\begin{array}{l}\text { Small, transparent, slight } \\
\text { yellow }\end{array}$ & Gram negative \\
\hline Bacillus cereus (SUB64) & $\begin{array}{l}\text { Small, irregular, rough, } \\
\text { opaque, white }\end{array}$ & Gram Positive \\
\hline Bacillus massiliogorillae (SUB65) & $\begin{array}{l}\text { Small, irregular, rough, } \\
\text { opaque, white }\end{array}$ & Gram positive \\
\hline Klebsiella pneumoniae (SUB66) & $\begin{array}{l}\text { Transparent, slight yellow, } \\
\text { small, round }\end{array}$ & Gram negative \\
\hline Pseudomonas congelans (SUB67) & $\begin{array}{l}\text { Small, transparent, } \\
\text { regular }\end{array}$ & Gram negative \\
\hline Bacillus subterraneus (SUB68) & $\begin{array}{l}\text { Big, irregular, rough, } \\
\text { opaque, creamish white }\end{array}$ & Gram positive \\
\hline Microvirga aerilata (SUB69) & $\begin{array}{l}\text { Round, transparent, } \\
\text { smooth, pink }\end{array}$ & Gram negative \\
\hline
\end{tabular}

In this work, nine bacterial strains isolated from different contaminated tissue culture tubes were initially designated as SUB61-SUB69 these bacteria were primarily differentiated based on their colony characters and cell arrangement (Table 3). Each isolates were further identified based on DNA sequencing. For their molecular identification DNA was extracted from all bacterial strains. It is a CTAB-based extraction procedure and it removes polysaccharides during DNA purification. In the present study, using the universal primer set, 1517bp DNA fragment of the $16 \mathrm{~S} r D N A$ gene was amplified by PCR (Fig. 4). For appropriate amplification of the gene, 
a template DNA must be of high purity. If any impurity remains in the genomic DNA sample, it will interfere in PCR. The 1517bp PCR amplified $16 S$ rDNA region was sequenced because it composed of both variable and conserved regions. The sequence obtained from SUB61 - SUB69 was compared to $16 S$ rDNA gene sequences available in the NCBI database by BLASTn homology search, as described by Altschul et al. (1990). The strain SUB57, SUB58, SUB59, SUB60, SUB61, SUB62 and SUB63 showed similarity with Kocuria palustris, Enterobacter cloacae, Aeromonas caviae, Bacillus cerus, Bacillus massiliogorille, Bacillus subterraneus and Microvirga aerilata, respectively (Table 4).

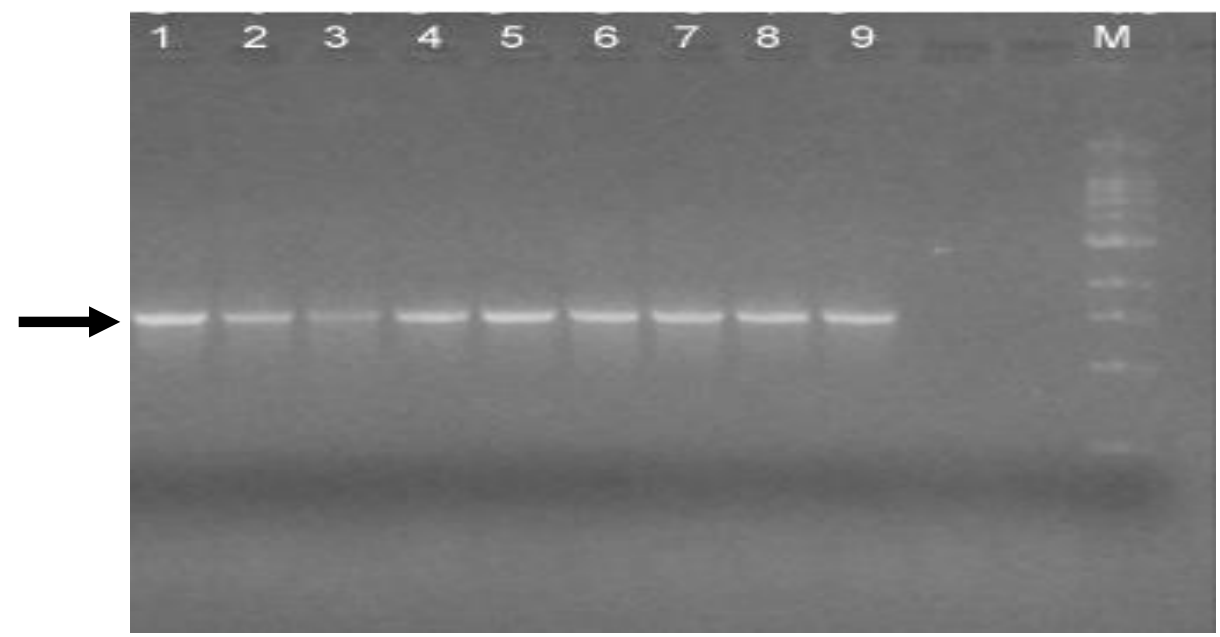

Figure 4. Agarose gel electrophoresis of amplified 16s $r D N A$ gene, 1517bp product using universal primer (lane 1, 2, 3, 4, 5, 6, 7, 8, 9 and M contains: SUB61, SUB62, SUB63, SUB64, SUB65, SUB66, SUB67, SUB68, SUF69 and marker, respectively).

Table 4. Bacteria isolated from tissue culture materials and sequence accession number.

\begin{tabular}{|c|c|c|c|c|}
\hline S.N. & Name of Bacteria & Isolation source & Accession No. & Similarity $(\%)$ \\
\hline 1 & Kocuria palustris (SUB61) & Punica granatum & MK779319 & 91 \\
\hline 2 & Enterobacter asburiae (SUB62) & Punica granatum & MK779326 & 90 \\
\hline 3 & Aeromonas caviae (SUB63) & Gossypium hirsutum & MK779325 & 95 \\
\hline 4 & Bacillus cereus (SUB64) & Gossypium hirsutum & MK779323 & 95 \\
\hline 5 & Bacillus massiliogorillae (SUB65) & Gossypium hirsutum & MK779712 & 92 \\
\hline 6 & Klebsiella pneumoniae (SUB66) & Ocimum sanctum & MK779743 & 100 \\
\hline 7 & Pseudomonas congelans (SUB67) & Ocimum sanctum & MK779744 & 96 \\
\hline 8 & Bacillus subterraneus (SUB68) & Carica papaya & MK779745 & 95 \\
\hline 9 & Microvirga aerilata (SUB69) & Rosa indica & MK779746 & 96 \\
\hline
\end{tabular}

Previously Odutayo et al. (2007) reported the Pseudomonas flourescens, Escherichia coli, Proteus sp., Micrococcus sp., Streptococcus pneumoniae, Staphylococcus aureus, Bacillus cereus, Bacillus subtilis, Corynebacterium sp. and Erwinia sp. like bacterial contamination in plant tissue culture of Hibiscus cannabinus and Telfaria occidentalis. Hennerty et al. (1988) found the Actinomycete as contamination in plant tissue culture of apple rootstocks. Microorganisms are small living biological environmental contaminant that can be transmitted very easily by air, infected people and animals.

The isolated all the organism i.e. Aspergillus leporis, Fusarium solani, Rhizopus oryzae, Clitopilus giovanellae, Simplicillium obclavatum, Fusarium solani, Pseudocercospora hakeae, Kocuria palustris, Enterobacter cloacae, Aeromonas caviae, Bacillus cerus, Bacillus massiliogorille, Bacillus subterraneus and Microvirga aerilata are major common bacterial and fungal contaminants of different plant in vitro cultures. These findings suggest that the identified microbial contaminants from the different plant in vitro culture can effectively be suppressed by using the specific antibiotic and antifungal agents.

\section{ACKNOWLEDGEMENTS}

Authors are thankful to Vimal Research Society for Agro-Biotech and Cosmic Powers, Rajkot and Department of Higher Education State Government and Department of Biosciences, Saurashtra University, Rajkot, Gujarat, India for providing lab facilities.

\section{REFERENCE}

Altschul SF, Gish W, Miller W, Myers EW \& Lipman DJ (1990) Basic local alignment search tool. Journal of Molecular Biology 215: 403-410. 
Bhargava P, Ravindra N \& Singh G (2018) A modified and improved protocol development for in vitro clonal propagation of Santalum album L. from internodal explants. Tropical Plant Research 5(2): 193-199.

Borpuzari PP \& Bisht NS (2018) Enhanced rhizome induction and fast regeneration protocol in liquid culture of Dendrocalamus longispathus Kurz: a single step culture. Tropical Plant Research 6(1): 18-23.

Cassells AC (1991) Problems in tissue culture: culture contamination. In: Debergh PC \& Zimmerman RH (eds) Micropropagation. Springer, Dordrecht, pp. 31-44.

Cassells AC (2012) Pathogen and biological contamination management in plant tissue culture: phytopathogens, vitro pathogens, and vitro pests. In: Loyola-Vargas V \& Ochoa-Alejo N (eds) Plant Cell Culture Protocols: Methods in Molecular Biology (Methods and Protocols). Humana Press, Totowa, N.

Chen AJ, Sun BD, Houbraken J, Frisvad JC, Yilmaz N, Zhou YG \& Samson RA (2016) New Talaromyces species from indoor environments in China. Studies in Mycology 84: 119-144.

Chudasama KS \& Thaker VS (2012) Screening of potential antimicrobial compounds against Xanthomonas campestris from 100 essential oils of aromatic plants used in India: An ecofriendly approach. Archives of Phytopathology and Plant Protection 45(7): 783-795.

Danby S, Berger, Howitt F, Wilson DJ, Dawson AR \& Leifert SC (1994) Fungal contaminants of primula, coffea, musa and iris tissue cultures. In: Lumsden PJ, Nicholas JR, \& Davies WJ (eds) Physiology, growth and development of plants in culture. Kluwer Academic Publishers, Dordrecht, pp. 397-403.

Debergh P \& Maene L (1984) Pathological and physiological problems related to the in vitro culture of plants. Parasitica 40: 69-75.

Egbuta MA, Mwanza M \& Babalola OO (2017) Health risks associated with exposure to filamentous fungi. International Journal of Environmental Research and Public Health 14: E719

George EF (1993) Plant propagation by tissue culture. Exergetics Ltd., Edington, England, pp. 574.

Hassan SAM \& Zayed NS (2018) Factor Controlling Micropropagation of Fruit Trees: A Review. Science International 6: 1-10.

Hennerty MJ, Upton ME, Furlong PA, James DJ, Harris DP \& Eaton RA (1988) Microbial contamination of in vitro cultures of apple root stocks M26 and M9. Acta Horticulturae 225: 129-138.

Hussain A, Qarshi IA, Nazir H \& Ullah I (2012) Plant tissue culture: current status and opportunities. In: Leva A \& Rinaldi LMR (eds) Recent advances in plant in vitro culture. InTech, Rijeka, pp. 1-28.

Kane M (2003) Bacterial and fungal indexing of tissue cultures. Available from: http://plant-c.cfansumn.edu /listerv/1996/log9612/indexing.htm (accessed: 12 May 2019).

Kannan K, Kumar DM, Ramya P, Nika SM, Meenatchi G, Sowmya AN \& Bhuvaneswari S (2014) Diversity of endophytic fungi from salt tolerant plants. International Journal of ChemTech Research 6: 4084-4088.

Kolomiets TM, Malyarovskaya VI, Gvasalia MV, Samarina LS \& Sokolov RN (2014) Micropropagation of subtropical fruit, ornamental crops and endemics of western caucasus: original and optimized protocols. Agricultural Biology 3: 49-58.

Leifert C \& Cassells AC (2001) Microbial hazards in plant tissue and cell cultures. In Vitro Cellular \& Developmental Biology Plant 37(2): 133-138.

Malyarovskaya V \& Samarina L (2017) In vitro Morphogenesis of ornamental shrubs Camellia japonica and Hydrangea macrophylla. Plant Tissue Culture and Biotechnology 27(2): 181-187.

Masumi S, Mirzaei S, Zafari D \& Kalvandi R (2015) Isolation, identification and biodiversity of endophytic fungi o Thymus. Progress in Biological Sciences 1: 43-50.

McCown BH (1986) Woody Ornamentals, Shade Trees, and Conifers. In: Zimmerman RH, Griesbach RJ, Hammerschlag FA \& Lawson RH (eds) Tissue culture as a plant production system for horticultural crops. Current Plant Science and Biotechnology in Agriculture, Springer, Dordrecht, pp. 333-342.

Miller JD, LaFlamme AM, Sobol Y, Lafontaine P \& Greenhalgh R (1988) Fungi and fungal products in some canadian homes. International Biodeterioration 24: 103-120.

More TT, Yan S, Tyagi RD \& Surampalli RY (2010) Potential use of filamentous fungi for wastewater sludge treatment. Bioresource Technology 101: 7691-7700.

Msogoyo T, Kanyagha H, Mutigitu J, Kulebelwa M \& Mamiro D (2012) Identification and management of microbial contaminants of banana in vitro cultures. Journal of Applied Bioscience 55: 3987-3994.

Murashige T \& Skoog F (1962) A revised medium for rapid growth bioassays with tobacco tissue cultures. Physilogia Plantarum 15: 473-497.

Odutayo OI, Amusa NA, Okutade OO \& Ogunsanwo YR (2007) Sources of microbial contamination in tissue culture laboratories in south western Nigeria. African Journal of Agricultural Research 2(3): 067-072. 
Odutayo OI, Oso RT, Akinyemi BO \& Amusa NA (2004) Microbial conterminats of cultured Hibiscus cannabalis and Telfaria occidenttalis cultured tissue. African Journal of Biotechnology 3: 301-307.

Rabari VP, Chudasama KS \& Thaker VS (2018) In vitro screening of 75 essential oils against Colletotrichum gloeosporioides: A causal agent of anthracnose disease of mango. International Journal of Fruit Science 18(1): 1-13.

Rout GR \& Jain SM (2004) Micropropagation of ornamental plants - cut flowers Propagation of Ornamental Plants 4(2): 3-28.

Sharma A \& Agrawal V (2012) Tissue culture aspects of ornamental plants. Journal of Biotechnology 1(1): 2319-3859.

Singh CR (2018) Review on problems and its remedy in plant tissue culture. Asian Journal of Biological Sciences 11: 165-172.

Singh G \& Shetty S (2011) Impact of tissue culture on agriculture in India. Society for Applied Biotechnology 1(2): 147-188.

Tolera B, Diro M \& Belew D (2014) In vitro aseptic culture establishment of sugarcane (Saccharum officinarum L.) varieties using shoot tip explants. Advances in Crop Science and Technology 2: 128.

You YH, Yoon H, Kang SM, Shin JH, Yeon-Sik Choo, Lee IJ, Lee JM \& Kim JG (2012) Fungal diversity and plant growth promotion of endophytic fungi from six halophytes in Suncheon Bay. Journal of Microbiology and Biotechnology 11: 1549-1556. 